\title{
Implementasi Pembelajaran Daring dan Luring bagi Anak Usia Dini pada Masa Pandemi Covid-19
}

\author{
${ }^{1}$ Fitri Febri Handayani, ${ }^{2}$ Hibana, ${ }^{3}$ Susilo Surahman \\ ${ }^{1}$ Universitas Islam Negeri Sunan Kalijaga, Yogyakarta, Indonesia \\ ${ }^{2}$ Universitas Islam Negeri Sunan Kalijaga, Yogyakarta, Indonesia \\ ${ }^{3}$ Institusi Agama Islam Negeri Surakarta, Jawa Tengah, Indonesia
}

\section{INFORMASI \\ ARTIKEL}

Artikel Histori:

Diterima :

25/06/2021

Direvisi :

17/07/2021

Diterbitkan:

31/07/2021

\section{Keywords: \\ Online learning, \\ Offline learning, \\ Covid-19}

Kata Kunci:

Pembelajaran

daring,

Pembelajaran

luar jaringan,

Covid-19

\section{DOI:}

https://doi.org

$\angle 10.46963 / \mathrm{mas}$

h.v4i02.358

\section{Korespondensi \\ Penulis: \\ Fitri Febri \\ Handayani \\ fitrifebrialhami \\ d@gmail.com}

\begin{abstract}
Corona outbreak or covid-19 that has occurred since 2019 impacts on psychology and human behavior, including the education system in Indonesia, that is broader in a long time. Here teachers and students must adapt online and/or offline learning systems to carry out the learning process. This study is to recognize the implementation of those two learning system for early childhood during the Covid-19 pandemic, especially at PAUD AsShofa Tembilahan Hulu for the A.Y. 2020/2021. The study is a qualitative decriptive. The data were collected through the use of observation, interview, and documentation. Data analysis used a triangulation on the Miles and Hiberman model. The results showed that PAUD As-Shofa Tembilahan Hulu used various approaches in these both learning system, includes: Home Visits, Limited Face-to-face Learning, and Learning from Home.
\end{abstract}

ABSTRAK: Wabah Corona atau Covid-19 yang tejadi sejak tahun 2019 berdampak pada psikologi dan tingkah laku manusia, termasuk sistem pendidikan di Indonesia, yang sifatnya lebih luas dalam rentang waktu yang tidak sebentar. Pada masa ini, guru dan anak didik harus beradaptasi dengan sistem pembelajaran daring dan/atau luring dalam melaksanakan proses pembelajaran. Tujuan dari penelitian ini ialah untuk mengetahui implementasi pembelajaran daring dan luring bagi anak usia dini pada masa pandemi Covid-19, khususnya di PAUD As-Shofa Tembilahan Hulu T.A. 2020/2021. Penelitian ini menggunakan pendekatan deskriftif kualitatif. Subjek penelitian kepala sekolah dan guru PAUD As-Shofa Tembilahan Hulu. Data dikumpulkan dengan menggunakan teknik observasi, wawancara dan dokumentasi. Analisis data menggunakan triangulasi model Miles dan Hiberman. Hasil penelitian menunjukkan bahwa PAUD As-Shofa Tembilahan Hulu menggunakan berbagai pendekatan dalam pembelajaran daring dan/atau luring di masa pandemi yang meliputi: kunjungan Rumah (Home Visit), Belajar Tatap Muka Terbatas, dan Belajar Dari Rumah.

\section{Cara mensitasi artikel:}

Handayani, F. F., Hibana, \& Surahman, S. (2021). Implementasi Pembelajaran Daring dan Luring bagi Anak Usia Dini pada Masa Pandemi. Mitra Ash-Shibyan: Jurnal Pendidikan dan Konseling, 4(02), 103-116. https://doi.org/10.46963/mash.v4i02.358 


\section{PENDAHULUAN}

Undang-Undang No. 20 tahun 2003 Bab 1, Pasal 1, Ayat 14 tentang Sistem pendidikan Nasional menyatakan bahwa pendidikan anak usia dini merupakan suatu pemberian rangsangan pendidikan untuk membantu pertumbuhan dan perkembangan fisik dan psikis dengan upaya pembinaan yang ditujukan kepada anak sejak lahir sampai enam tahun, agar anak memiliki persiapan terhadap pendidikan selanjutnya. Sementara itu, pendidikan sendiri memiliki arti suatu usaha sadar dan terencana untuk memberikan bimbingan dan pertolongan dalam mengembangkan potensi anak, baik fisik atau pun psikisnya, dimana pendidikan diberikan oleh pendidik baik guru/orangtua/orang dewasa kepada anak didik untuk mencapai kedewasaannya serta mencapai tujuan untuk menjadi manusia yang beriman, berilmu, berakhlak mulia, mandiri dan memiliki kreativitas yang dapat diterima di dalam masyarakat (Pratama \& Mulyati, 2020).

Pane (2017) berpendapat, pembelajaran adalah suatu proses adanya interaksi antara guru, anak didik dan materi ajar yang berlangsung dalam suatu lingkungan belajar. Firdaus (2020) menambahakan, pembelajaran dapat dikaakan berhasil apabila proses interaksi dalam pembelajaran berjalan dengan baik, baik dari komponen guru, anak didik maupun materi ajar. Akan tetapi pada 31 Desember 2019 dunia dikejutkan dengan munculnya wabah penyakit bernama corona desese yang terjadi Kota Wuhan, Cina. Virus ini memiliki kemampuan penyebaran yang cepat dan meluas (Herliandry, Nurhasanah, Suban, \& Kuswanto, 2020). Pandemi Covid-19 saat ini telah menjajah dunia tidak terkecuali negara Indonesia, dimana penyebaran penyakitnya sangat meluas dan cepat, mengakibatkan negara di penjuru dunia mengalami krisis kesehatan. Pada mulanya penyebaran virus ini sangat berakibat pada aktivitas perekonomian yang mulai menurun (Handarini et al., 2018). Menurut Lee (dalam Herliandry et al., 2020), wabah Covid-19 ini dapat memiliki akhiran yang berbeda pada setiap negara tergantung pada kebijakan yang diterapkan dan ketanggapan pemerintah guna meminimalkan penyebarannya.

Sehubungan dengan itu, pemerintah Indonesia mengeluarkan berbagai kebijakan-kebijakan terkait menyikapi pandemi Covid-19 demi mengurangi tingkat penyebarannya. Diantaranya larangan orang agar tidak berkumpul dan melaksanakan kegiatan di luar rumah dan 
menganjurkan agar tetap berada di rumah, beribadah di rumah, bekerja dari rumah (work from home) dan belajar dari rumah (school from home). Kemudian memberlakuan PSBB (pembatasan sosial berskala besar) pada beberapa daerah. Pada masa PSBB pemerintah mewajibkan masyarakat untuk selalu menjaga kesehatan dengan melakukan jaga jarak, menjaga kebersihan dengan selalu mencuci tangan atau memn akai handsanitizer dan selalu menggunakan masker ketika diluar rumah. Begitupula dengan pembatasan kegiatan interaksi masyarakat lainnya seperti phsycal distancing dan social distancing (Amalia \& Sa'adah, 2020; Kristina, Sari, \& Nagara, 2020; Mustakim, 2020).

Kebijakan-kebijakan tersebut dibuat guna meminimalisir meluasnya wabah Covid-19 yang berdampak luas pada berbagai sektor, termasuk sektor pendidikan di Indonesia (Handarini et al., 2018). Upaya yang dilakukan pada bidang pendidikan yaitu menggantisejenak aktivitas belajar di dalam kelas. Upaya itu dilaksanakan disemua tingkatan pendidikan di Indonesia, mulai dari Pendidikan Anak Usia Dini hingga perguruan tinggi (Firdaus, 2020).

Salah satu kebijakan pemerintah dalam sistem pendidikan di masa pandemi ini ialah melalui surat edaran Menteri Pendidikan dan Kebudayaan bahwa seluruh kegiatan dilaksanakan dengan sistem daring, yang dilaksanakan di rumah (Putria et al., 2020). Sebagai respon dari ditutupnya sekolah-sekolah dikarenakan pandemi Covid-19, pembelajaran jarak jauh menjadi satu di antara jalan keluar yang ditawarkan oleh pemerintah agar pembelajaran tetap berjalan seperti biasanya. Pembelajaran jarak jauh merupakan pembelajaran dengan kondisi dimana guru dan anak didik tidak bertatap muka secara langsung dan tidak berkumpul bersama pada satu tempat secara rutin untuk menerima pembelajaran secara langsung (Prawiyogi et al., 2020).

Selain itu, pembelajaran daring (online learning) juga dapat menjadi solusi atas penyelenggaraan pembelajaran pada masa pandemi ini (Nengrum et al., 2021). Pembelajaran daring adalah pembelajaran yang memanfaatkan internet (network) dengan aksebilitas, konektivitas, fleksibilitas, dan keahlian dalam mengadakan berbagai jenis interaksi dalam pembelajaran (Sadikin \& Hamidah, 2020). Salah satu manfaat belajar dalam jaringan dapat memberikan kebebasan bagi semua orang untuk mengakses pembelajaran tanpa terhambat pembelajaran secara langsung di dalam kelas (Fitriyani et al., 2020). 
Pembelajaran daring mempunyai karakteristik konstruktivisme sosial, konstruktivisme, pembelajaran berbasis komputer/internet, aksesabilitas, pembelajaran inklusif, kemandirian, interaktivitas, dan refleksi. Pembelajaran daring adalahsatu kesatuan dari pembelajaran jarak jauh yang secara tersendirimemadukan teknologi berbasis internet dan teknologi elektronika (Asmuni, 2020).

Sedangkan luring merupakan kepanjangan dari "luar jaringan", dengan kata lain tidak tersambung dari jaringan komputer. Sebagai contoh belajar menggunakan buku ajar atau buku pegangan, pertemuan secara langsung, menonton TVRI sebagai media pembelajaran dan anak didik mengumpulkan karyanya berupa foto atau video, dikarenakan pembelajaran luring menggunakan media lain selain jaringan komputer artinya tidak tersambung ke jaringan computer (Malyana, 2020).

Berdasarkan pemaparan di atas, penelitian ini bertujuan untuk mengetahui bagaimana implementasi pembelajaran daring dan luring bagi anak usia dini pada masa pandemi Covid-19, khususnya di PAUD As-Shofa Tembilahan Hulu Tahun Akademik 2020/2021.

\section{METODE PENELITIAN}

Penelitian ini menggunakan pendekatan kualitatif, karena pendekatan ini dirasa lebih sesuai untuk menggambarkan kondisi yang sedang dirasakan saat ini, yaitu Covid-19. Penelitian ini dilakasanakan di PAUD As-Shofa Tembilahan Hulu Tahu Akademik 2020/2021. Sumber data dalam penelitian ini adalah sumber data primer (kepala sekolah dan guru kelas) dan sumber data sekunder (buku, jurnal, dan dokumentasi). Teknik pengumpulan data menggunakan teknik triangulasi data, berupa observasi, wawancara dan dokumentasi. Analisis data menggunakan model Miles Huberman yang terdiri dari mengumpulkan data, mereduksi data, penyajian data dan penarikan kesimpulan (Setiawan \& Sisilia, 2020).

\section{HASIL DAN PEMBAHASAN}

\section{Kunjungan Rumah (Home Visit)}

Kunjungan rumah atau home visit adalah pembelajaran yang dilaksanakan secara tatap muka atau luring yang merupakan suatu pengupayaan yang diterapkan guru dalam pembelajaran dimasa pandemi Covid-19 (Budiyanti \& Melati, 2020). Kunjungan rumah juga merupakan bagian dari kegiatan bimbingan konseling dalam rangka pegumpulan dan memenuhi data maupun informasi anak didik dan bertujuan untuk 
memecahkan persoalan yang dihadapi anak didik (Amalia, 2016). Lebih lanjut, Amalia (2016) menjelaskan, kunjungan rumah juga bertujuan untuk mengatasi kesulitan belajar pada anak didik dan merupakan tindakan pencegahan terjadinya diskomunikasi guru dan anak didik dalam pembelajaran online dimasa pandemi covid-19.

Tujuan khusus dari kunjungan rumah ialah untuk memudahkan guru memperoleh informasi beragam aktivitas yang dilakukan oleh anak didik saat berada dirumah. Sebagai penegasan bahwa kunjungan rumahdilaksanakan dalam upayamempererat kerjasama dengan orangtua anak didik untuk menganalisis tentang cara belajar anak, ibadah dan kendala yang dihadapi anak saat belajar. Guru mlaksanakan kunjungan rumah dalam waktu tertentu yang telah disepakati oleh kepala sekolah, guru kelas dan orangtua anak didik, dalam kegiatan ini guru berperan sebagai pembimbing (Mokodompit, 2020).

Awal pembelajaran tahun akademik 2020/2021 di PAUD AsShofa Tembilahan Hulu dimulai dengan menggunakan pembelajaran Kunjungan Rumah (Home Visit), yang dilaksanakan pada semester 1, minggu pertama pada tanggal 20 Juli 2020 hingga minggu ke-6 pada tanggal 24 Agustus 2020. Dalam kegiatan kunjungan rumah ini guru melaksanakan kunjungan satu kali seminggu per anak dengan durasi waktu 30-40 menit.

Pada pembelajaran kunjungan rumah di PAUD As-Shofa Tembilahan Hulu guru hanya memfokuskan pada kegiatan inti, dikarenakan waktu yang diberikan hanya 30-40 menit per anak, dalam pembelajaran ini guru mendampingi atau membimbing anak secara perseorangan dalam melaksanakan kegiatan yang telah dibuat berdasarkan RPPH. Pembelajaran dimulai dari guru bersama anak membaca do'a sebelum belajar, kemudian pembelajaran langsung di fokuskan pada kegiatan yang akan dilaksanakan anak. Jumlah kegiatan yang anak laksanakan pada Kunjungan Rumah ini berbeda dengan jumlah kegiatan sebelum pandemi, jika jumlah kegiatan sebelum pandemi anak melaksanakan 4 kegiatan, maka pada kunjungan rumah ini (masa pandemi) anak hanya mengerjakan 1 kegiatan, semisal menulis huruf " $\mathrm{A}$ " atau menggambar, mewarnai, meronce dan kegiatan lainnya. Jika anak telah selesai mengerjakan kegiatannya dan masih memiliki waktu maka waktu tersebut guru manfaatkan untuk mengaji Iqro' kemudian pembelajaran ditutup dengan mengucap Alhamdulillah dan Do'a setelah 
belajar. Mengenai menyetoran hafalan surah pendek, hadist pendek dan do'a-do'a pendek dilaporkan di penghujung minggu melalui WhatsApp dalam bentuk video atau voice note yang dikirim kepada wali kelas. (Hasil wawancara pada hari Senin, 24 Mei 2021).

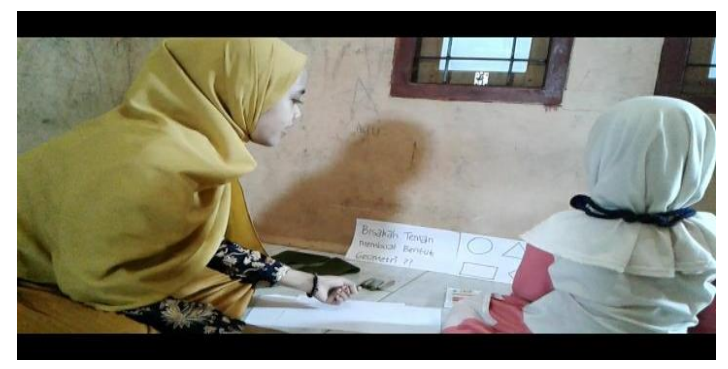

Gambar 1. Kunjungan Rumah yang dilaksanakan guru pada awal pembelajaran Tahun Akademik 2020/2021.

\section{Belajar Tatap Muka Terbatas}

Pembelajaran langsung di masa pandemi Covid-19 ini merupakan pembelajaran yang mempunyai ciri khusus dari pembelajaran langsung sebelum pandemi, tetapi pembelajaran ini cukup ampuh diterapkan untuk anak usia dini dibanding dengan pembelajaran daring atau dalam jaringan (Annisa, 2021). Belajar tatap muka merupakan pembelajaran klasikal dimana guru dan anak didik bertemu secara langsung face to face dalam suatu ruangan atau tempat perkumpulan yang sama (Anggrawan, 2019).

Disusul dengan siaran pers No.137/sipres/A6/VI/2020 mengenai penyelenggaraan pembelajaran pada tahun ajaran dan tahun akademik baru di masa pandemi Covid-19, salah satu poin pentingnya ialah penyelenggaraan pembelajaran tatap muka boleh dilakukan pada zona hijau dengan tetap memperhatikan protokol kesehatan. Hal ini menjadikan beberapa wilayah Indonesia yang dalam kategori zona hijau melakukan kegiatan pembelajaran secara tatap muka (Nissa \& Haryanto, 2020).

Kemudian dari pada itu pemerintahan Indragiri Hilir resmi membuka pembelajaran tatap muka secara terbatas yang dikeluarkan melalui surat edaran Nomor 187.13/Disdik-SET-UM/2021 tentang pelaksanaan pembelajaran tatap muka terbatas bagi seluruh satuan pendidikan, yang dilaksanakan mulai dari tanggal 15 Februari 2021 (disdik.inhil.go.id).

108 mitra Ash-Shibyan: Jurnal Pendidikan dan Konseling|Vol. 4, No. 02(2021) Licensed under CC-BY-SA (c) (1) () 
Berdasarkan siaran pers No.137/sipres/A6/VI/2020 dan surat edaran Nomor 187.13/Disdik-SET-UM/2021 tersebut, PAUD As-shofa Tembilahan Hulu, melaksanakan pembelajaran tatap muka terbatas. Pembelajaran tatap muka terbatas di PAUD As-Shofa Tembilahan Hulu dilaksanakan 3 kali seminggu yang diadakan 2 kali seminggu di rumah guru dan satu kali seminggu di mushola PAUD As-Shofa Tembilahan Hulu. Pembelajaran tatap muka ini dilaksanakan dengan tetap mengikuti protokol kesehatan yang telah ditetapkan pemerintah yaitu memakai masker ketika belajar dirumah guru, mencuci tangan sebelum masuk kerumah guru dan menjaga jarak dengan teman satu ruangan begitu juga ketika anak belajar di mushola.

Belajar tatap muka terbatas dilaksanakan di semester 1 pada minggu ke-7 tanggal 31 Agustus 2020 hingga minggu ke-9 tanggal 14 September 2020. Kemudian pembelajaran tatap muka terbatas kembali dilaksanakan pada minggu ke-14,tanggal 19 Oktober 2020 sampai minggu ke-17, tanggal 9 November 2020. Pada semester 2 belajar tatap muka kembali dilaksanakan pada minggu ke-7, tanggal 15 Februari 2021 sampai minggu ke-17, tanggal 1 Juni 2021 (Hasil wawancara pada hari Senin, 24 Mei 2021).

Pada Kegiatan pembelajaran tatap muka terbatas yang dilaksanakan di PAUD As-Shofa Tembilahan Hulu memiliki sistem pembelajaran yang sama seperti pembelajaran tatap muka sebelum masa pandemi yang meliputi Kegiatan Pembuka, Inti, Istirahat/Makan dan Penutup (Yuniatari, 2020). Yang menjadikannya berbeda adalah dalam hal jumlah kegiatan, jika pada tatap muka sebelum pandemi di kegiatan inti anak mengerjakan 4 kegiatan, maka di masa pandemi ini anak hanya mengerjakan 1 kegiatan. Kemudian itu pembelajaran tatap muka sebelum pandemi PAUD As-Shofa Tembilahan Hulu menggunakan model pembelajaran kelompok dengan kegiatan sudut pengaman.

Mengenai model pembelajaran kelompok dengan kegiatan sudut pengaman yang diterpkan di PAUD As-Shofa Tembilahan Hulu sebelum masa pandemic, anak mengerjakan kegiatan berdasarkan kelompokkelompok yang sudah ditata, sehingga ketika anak mengerjakan kegiatan anak-anak akan dibagi ke dalam beberapa kelompok berdasarkan kegiatan yang telah ditata tersebut. Anak yang sudah siap mengerjakan kegiatan di kelompoknya boleh berpindah ke kelompok lain. Fungsi dari kegiatan sudut pengaman adalah untuk mengamankan anak yang telah 
mengerjakan kegiatan di semua kelompok atau anak yang belum mendapatkan tempat dikelompok lain. Dimana pada kegiatan sudut pengaman ini guru menyediakan banyak mainan agar anak bisa bermain didalamnya dan tidak menganggu temannya yang belum siap mengerjakan kegiatan(Syamsuardi, 2018), namun pada masa pandemi ini model kegiatan ini tidak dilaksanakan, dikarenakan anak hanya mengerjakan 1 kegiatan dan model pembelajaran yang diterpkan adalah model klasikal.

Adapun proses pembelajaran tatap muka terbatasyang dilaksanakan di PAUD As-Shofa Tembilahan Hulu meliputi:

\section{Kegiatan pembuka ( \pm 30 menit)}

Kegiatan pendahuluan diterapkan menggunakan model klasikal, artinya kegiatan ini dipimpin oleh guru dan diikuti oleh seluruh anak. Kegiatan pendahuluan ini bersifat pemanasan dan pembiasaan yang meliputi: tegur sapa guru dengan anak seperti menanya kabar, menanya siapa yang tidak hadir dan menanya hal lain yang membuat anak bersemangat, kemudian dilanjutkan dengan kegiatan berdo'a, bernyanyi 'Selamat Pagi Bu' diiringi dengan gerakan bertepuk tangan, bersholawat, membaca surah-surah pendek dan yang terakhir dari kegiatan pendahuluan yakni guru bercerita tentang tema pembelajaran hari ini.

\section{Kegiatan Inti ( \pm 30 menit)}

Kegiatan inti merupakan proses untuk memperoleh kompetensi dasaroleh karena itu kegiatan ini harus dilaksanakan dengan menyenangkan, menantang, memotivasi agar anak didik aktif berpartisipasi. Dalam kegiatan ini anak melaksanakan kegiatan secara klasikal yang terlebih dahulu diberi arahan oleh guru, setelah anak mengerjakan kegiatan anak diharapkan membereskan dan meletakkan kembali peralatan tulisnnya di tempat yang telah disediakan. Sembari menunggu temannya yang belum selesai, anak-anak diperbolehkan main menggunakan permainan yang telah disediakan di dalam kelas.

\section{Istirahat/Makan ( \pm 30 menit)}

Kegiatan istirahat/makan ini merupakan kegiatan dimana anak bisa beristirahat setelah mengerjakan kegiatan yang diselingi dengan kegiatan makan bersama. Pada kegiatan ini dapat dimanfaatkan untuk memperoleh perkembangan anak dibidang sosial emosional, kedisiplinan, adab makan, makanan yang bergizi untuk dimakan, saling berbagi,

110 mitra Ash-shibyan: Jurnal Pendidikan dan Konseling|Vol. 4, No. 02(2021) Licensed under CC-BY-SA (c) (1) () 
kerjasama dan lainnya. Setelah anak selesai makan anak diperbolehkan untuk bermain permainan outdoor yang bertujuan mengembangkan fisik/motorik dan interaksi sosial.

\section{Kegiatan Penutup $( \pm 30$ menit)}

Kegiatan ini merupakan langkan terakhir dalam proses pembelajaran, prinsipnya tidak jauh berbeda dari kegiatan pembuka, yaitu mengenai pembiasaan, yang meliputi: refleksi atau umpan balik dari apa yang telah anak pelajari hari ini dilanjutkan dengan pesan-pesan, membaca hadist pendek, berdo'a, menyanyikan lagu 'illa liko illa liko' dan salam.

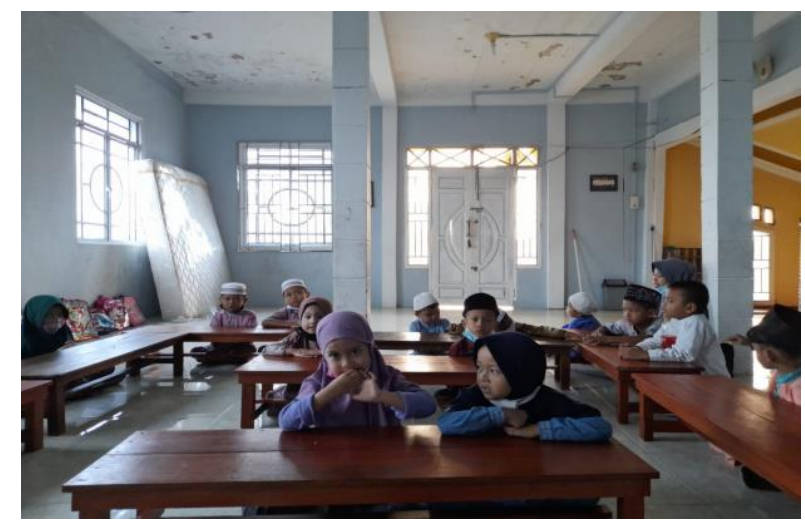

Gambar 2. Pembelajaran tatap muka terbatas di PAUD As-Shofa Tembilahan Hulu yang dilaksanakan di rumah guru kelas.

\section{Belajar dari Rumah (BDR)}

Belajar dari rumah (BDR) atau School from home (SFH) adalah salah satu upaya yang dilakukan untuk menghambatmeluasnya Covid-19. Peraturan ini harusditaati, terutama pada daerah zona merah. Dengan mengaplikasikan Belajar Dari Rumah (BDR) ini berarti telah menerapkan pembelajaran jarak jauh yaitu dengan memanfaatkan teknologi digital yang berbasis multimedia (Lutfiyah \& Roviati, 2020).

Belajar dari Rumah (BDR) merupakan sebuah proses pembelajaran yang dilakukan oleh anak didik dan guru dirumah masingmasing (Prasetyaningtyas, 2021). Prinsip pelaksanaan Belajar Dari Rumah adalah anak didik dapat mengaskses bahan ajar dan materi ajarkapan saja dan dimana saja. Kegiatan pembelajaran ini dimaksudkan untuk mempermudah dalam pemberian bahan ajar kepada anak didikserta bagian dari proses pembelajaran jarak jauh(Kurniasari et al., 2020). Adapun beberapa teknologi digital yang dapat digunakan untuk 
membantu jalannya pendidikan yang dilaksanakan dirumah seperti WhatsApp, Zoom, Google Class Room (GCR), Facebook, dan lainnya (Eriani \& Amiliya, 2020)

Belajar Dari Rumah (BDR) dilaksanakan di PAUD As-Shofa Tembilahan Hulu pada semester 1 di minggu ke-10 sampai minggu ke-13, pada tanggal 21 September 2020 sampai 12 Oktober 2020. Kembali dilaksanakan di semester 2 pada minggu pertama sampai minggu ke-6, berlangsung dari tanggal 4 Januari 2021 sampai 8 Februari 2021. Proses pembelajaran dimulai dari orangtua menerima RPPM (kegiatan yang akan anak kerjakan selama seminggu) dan RPPH serta alat dan bahan pembelajaran.

Dalam Belajar Dari Rumah (BDR) ini orangtua berperan sebagai pembimbing anak, proses pembelajaran meliputi: berdo'a sebelum dan sesudah melaksanakan kegiatan, muroja'ah surah pendek, membaca do'ado'a pendek, membaca hadist pendek, menyanyikan 1 lagu anak-anak disertai gerakan-gerakan bebas, anak mengerjakan 2 kegiatan perhari, contoh menulis kata "Bulan". Dan, anak bersama orangtua bermain bebas memanfaatkan benda-benda di rumah yang berbentuk lingkaran.

Kegiatan perhari boleh dipilih sesuai minat anak, tidak mesti harus berurutan berdasarkan RPPM. Kegiatan yang telah selesai dikerjakan dilaporkan ke WhattApp wali murid berupa foto atau video. Kepada orangtua diharapkan dapat mengikuti pembelajaran yang disiarkan TVRI setiap hari senin - Jum'at pukul 08:00 - 08:30 yang dilaporkan berupa video atau foto kepada wali kelas.Hafalan hadist, surah pedek dan do'a pendek dilaporkan pada hari Jum'at, sedangkan kegiatan olahraga dan bernyanyi pada hari Sabtu, kegiatan ini dilaporkan dalam bentuk Video atau boleh voice note untuk setor hafalan yang akan dilaporkan ke WhatsApp wali kelas.Kemudian kegiatan anak selama seminggu diantarkan kesekolah pada penghujung minggu (hari Sabtu Minggu) dan oranguta sekalian mengambil RPPM dan RPPH serta alat dan bahan pembelajaran dan kegiatan yang akan anak kerjakan untuk minggu selanjutnya(Hasil wawancara pada hari Senin, 24 Mei 2021).

112 mitra Ash-shibyan: Jurnal Pendidikan dan Konseling|Vol. 4, No. 02(2021) Licensed under CC-BY-SA (c) (1) () 


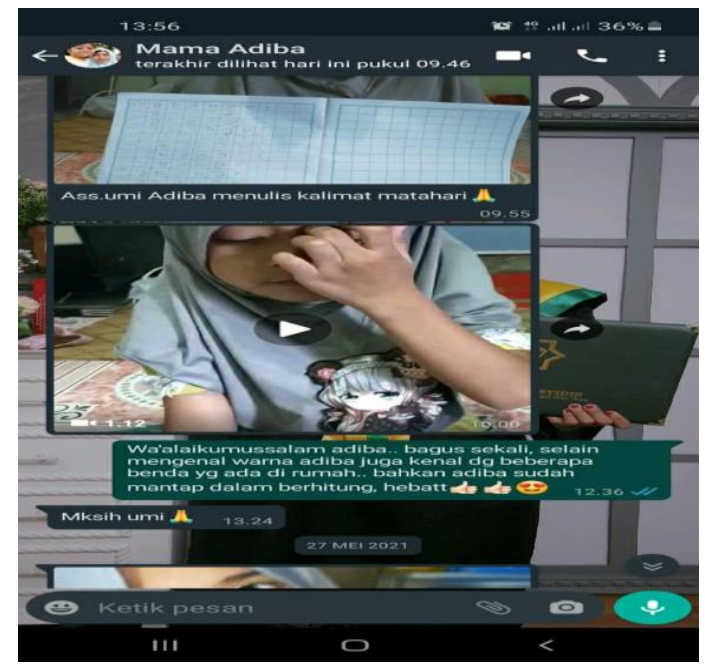

Gambar 3. Belajar dari rumah yang dilaksanakan oleh anak didik

\section{SIMPULAN}

Untuk memutus mata rantai penyebaran Covid-19 di Indonesia khususnya di lingkungan pendidikan anak usia dini, maka PAUD AsShofa Tembilahan hulu melaksanakan pembelajaran daring dan luring sebagai solusi agar tetap terlaksananya proses pembelajaran. Hasil penelitian menunjukkan bahwa PAUD As-Shofa Tembilahan Hulu menggunakan berbagai pendekatan dalam pembelajaran daring dan luring di masa pandemi yang meliputi: kunjungan rumah (Home Visit), Belajar Tatap Muka Terbatas, dan Belajar Dari Rumah, dimana masingmasing pendekatan meiliki perbedaan dalam hal pelaksanaannya.

Peneliti berharap pembelajaran pada masa Covid-19 akan selalu berlangsung baik dan mencapai hasil yang telah ditargetkan dalam pembelajaran, baik menggunakan pembelajaran daring maupun menggunakan pembelajaran luring. Serta semoga hasil yang diperoleh dari penelitian ini bisa menjadi rujukan untuk penelitian selanjutnya.

\section{DAFTAR PUSTAKA}

Amalia, A., \& Sa'adah, N. (2020). Dampak Wabah Covid-19 Terhadap Kegiatan Belajar Mengajar Di Indonesia. Jurnal Psikologi, 13(2), 214-225. https:// doi.org/10.35760/psi.2020.v13i2.3572

Amalia, H. (2016). Implementasi Home Visit dalam Upaya Meningkatkan Pembelajaran PAI di SDIT al-Azhar Kediri. Didaktika Religia, 4(1), 77-106. https://doi.org/10.30762/didaktika.v4.i1.p77-106.2016

Anggrawan, A. (2019). Analisis Deskriptif Hasil Belajar Pembelajaran Tatap Muka dan Pembelajaran Online Menurut Gaya Belajar Mahasiswa. 
MATRIK: Jurnal Manajemen, Teknik Informatika Dan Rekayasa Komputer, 18(2), 339-346. https:// doi.org/10.30812/matrik.v18i2.411

Asmuni, A. (2020). Problematika Pembelajaran Daring di Masa Pandemi Covid19 dan Solusi Pemecahannya. Jurnal Paedagogy, 7(4), 281. https://doi.org/10.33394/jp.v7i4.2941

Budianti., A., \& Melati, P. A. (2020). Implementasi Kunjungan Rumah Dalam Pembelajaran Pada Masa Pandemi. Academica. Comhar, 29(9), 18.

Eriani, E., \& Amiliya, R. (2020). Blended Learning: Kombinasi Belajar Untuk Anak Usia Dini. Mitra Ash-Shibyan, 3(1), 11-21. https://doi.org/10.46963/mash.v3i01.1112

Fadhillah, A. N. (2021). Peran Guru Pada Proses Pembelajaran Luring Dalam Perkembangan Sosial Emosional Anak Usia Dini Di Tk Islam Perkemas Bandar Lampung. Jurnal Universitas Islam Negeri Raden Intan Lampung.

Firdaus, F. (2020). Implementasi Dan Hambatan Pada Pembelajaran Daring di Masa Pandemi Covid 19. Utile: Jurnal Kependidikan, 6(2), 220-225. https://doi.org/10.37150/jut.v6i2.1009

Fitriyani, Y., Fauzi, I., \& Sari, M. Z. (2020). Motivasi Belajar Mahasiswa Pada Pembelajaran Daring Selama Pandemik Covid-19. Profesi Pendidikan Dasar, 7(1), 121-132. https://doi.org/10.23917/ppd.v7i1.10973

Herliandry, L. D., Nurhasanah, N., Suban, M. E., \& Kuswanto, H. (2020). Pembelajaran Pada Masa Pandemi Covid-19. JTP - Jurnal Teknologi Pendidikan, 22(1), 65-70. https://doi.org/10.21009/jtp.v22i1.15286

Kristina, M., Sari, R. N., \& Nagara, E. S. (2020). Model Pelaksanaan Pembelajaran Daring Pada Masa Pandemi Covid 19 Di Provinsi Lampung. Idaarah: $\begin{array}{llll}\text { Jurnal Manajemen } & \text { Pendidikan, }\end{array}$ https://doi.org/10.24252/idaarah.v4i2.16945

Kurniasari, A., Pribowo, F. S. P., \& Putra, D. A. (2020). Analisis Efektivitas Pelaksanaan Belajar Dari Rumah (Bdr) Selama Pandemi Covid-19. Jurnal Review Pendidikan Dasar: Jurnal Kajian Pendidikan Dan Hasil Penelitian, 6(3), $1-8$.

L., D., \& Murphy, M. W. (1970). Academica. Comhar, 29(9), 18. https://doi.org/10.2307/20552957

Lutfiyah, L., \& Roviati, E. (2020). Pendampingan Belajar Di Rumah Selama Masa Pandemi Covid-19. Dimasejati: Jurnal Pengabdian Kepada Masyarakat, 2(2), 181. https:// doi.org/10.24235/ dimasejati.v2i2.7015

Malyana, A. (2020). Pelaksanaan Pembelajaran Daring Dan Luring Dengan Metode Bimbingan Berkelanjutan Pada Guru Sekolah Dasar Di Teluk Betung Utara Bandar Lampung. Pedagogia: Jurnal Ilmiah Pendidikan Dasar Indonesia, 2(1), 67-76. https:/ / doi.org/10.52217/ pedagogia.v2i1.640

Mokodompit, I. S. (2020). Home Visit sebagai Refleksi Kurikulum Darurat Covid19: Kesiapan Guru, Respon Siswa , Materi dan Hasil Belajar di Madrasah Tsanawiyah Pendahuluan Peraturan Menteri Agama Republik Indonesia Nomor 60 Tahun 2015 Tentang Penyelenggaraan Pendidikan Madrasah , $6(2), 119-131$.

Mustakim, M. (2020). Efektivitas Pembelajaran Daring Menggunakan Media Online Selama Pandemi Covid-19 Pada Mata Pelajaran Matematika. Al

114 mitra Ash-shibyan: Jurnal Pendidikan dan Konseling|Vol. 4, No. 02(2021) Licensed under CC-BY-SA (c) (i) (2) 
Asma: Journal of Islamic Education, 2(1), 1. https://doi.org/10.24252/asma.v2i1.13646

Nengrum, T. A., Pettasolong, N., \& Nuriman, M. (2021). Kelebihan dan Kekurangan Pembelajaran Luring dan Daring dalam Pencapaian Kompetensi Dasar Kurikulum Bahasa Arab di Madrasah Ibtidaiyah 2 Kabupaten Gorontalo. Jurnal Pendidikan, 30(1), 1-12.

Nissa, S. F., \& Haryanto, A. (2020). Implementasi Pembelajaran Tatap Muka Di Masa Pandemi Covid-19. Jurnal IKA PGSD (Ikatan Alumni PGSD) UNARS, 8(2), 402. https://doi.org/10.36841/pgsdunars.v8i2.840

Pane, A. (2017). Belajar dan Pembelajaran Aprida Pane Muhammad Darwis Dasopang. Fitrah, 3(2), 333-352.

Peraturan Mentri Pendidikan Nasional Republik Indonesia No. 58 Tahun 2009 Tentang Standar Pendidikan Anak Usia Dini.

Prasetyaningtyas, S. (2021). Pelaksanaan Belajar dari Rumah (BDR) Secara Online Selama Darurat Covid-19 di SMP N 1 Semin. Jurnal Karya Ilmiah Guru, $5(1), 86-94$.

Pratama, R. E., \& Mulyati, S. (2020). Pembelajaran Daring dan Luring pada Masa Pandemi Covid-19. Gagasan Pendidikan Indonesia, 1(2), 49. https:// doi.org/10.30870/gpi.v1i2.9405

Prawiyogi, A. G., Purwanugraha, A., Fakhry, G., \& Firmansyah, M. (2020). Efektifitas Pembelajaran Jarak Jauh Terhadap Pembelajaran Siswa di SDIT Cendekia Purwakarta. Jurnal Pendidikan Dasar, 11(1), 94-101.

Putria, H., Maula, L. H., \& Uswatun, D. A. (2020). Analisis Proses Pembelajaran dalam Jaringan (DARING) Masa Pandemi Covid- 19 Pada Guru Sekolah Dasar. Jurnal Basicedu, 4(4), 861-870. https:// doi.org/10.31004/basicedu.v4i4.460

Rosali, E. S. (2020). Aktifitas Pembelajaran Daring Pada Masa Pandemi Covid-19 Di Jurusan Pendidikan Geografi Universitas Siliwangi Tasikmalaya. Geography Science Education Journal (GEOSEE), 1(1), 21-30.

Sadikin, A., \& Hamidah, A. (2020). Pembelajaran Daring di Tengah Wabah Covid-19. Biodik, 6(2), 109-119. https://doi.org/10.22437/bio.v6i2.9759

Syamsuardi, H. (2018). Penggunaan Model Pembelajaran pada Taman KanakKanak Kota Makassar. Jurnal CARE (Children Advisory Research and Education), 2(5), 1-7.

Wulandari, D. A., \& Muzakki, J. A. (2018). Implementasi Pendekatan Metode Montessori Dalam, Vol. 4, No, 1-19.

Yuniatari. (2020). Implementasi Model Pembelajaran Kelompok, Sudut, Area , dan Sentra dalam Pembelajaran Anak Usia Dini. Islamic EduKids: Jurnal Pendidikan Anak Usia Dini, 2(2), 35-57. 
Implementasi Pembelajaran Daring dan Luring bagi Anak Usia Dini pada Masa Pandemi Covid-19

Halaman ini dibiarkan kosong

116 mitra Ash-Shibyan: Jurnal Pendidikan dan Konseling|Vol. 4, No. 02(2021) Licensed under CC-BY-SA (c) (1) () 